\title{
Styrene Photocatalytic Degradation Reaction Kinetics
}

\author{
Silvio R. Taffarel, ${ }^{a}$ Marla A. Lansarin ${ }^{*}, a$ and Celso C. Moro ${ }^{b}$ \\ ${ }^{a}$ Departamento de Engenharia Química, Universidade Federal do Rio Grande do Sul, \\ Av. Eng. Luis Englert, s/n, 90040-040 Porto Alegre-RS, Brazil \\ ${ }^{b}$ Instituto de Química, Universidade Federal do Rio Grande do Sul, \\ Av. Bento Gonçalves, 9500, CP 150003, 91501-970 Porto Alegre-RS, Brazil
}

\begin{abstract}
A reação de degradação fotocatalítica do estireno foi estudada utilizando-se $\mathrm{TiO}_{2} \mathrm{P}-25$ (Degussa) como catalisador. Os experimentos foram realizados em um reator "slurry" em bateladas, com controle de temperatura, empregando-se uma lâmpada UV. Foram estudados os efeitos do $\mathrm{pH}$, da concentração inicial de estireno, da concentração do catalisador e da adição de $\mathrm{H}_{2} \mathrm{O}_{2}$ sobre a velocidade da reação. Os resultados mostraram que, em 90 min, cerca de $95 \%$ da quantidade inicial da molécula foi consumida por fotocatálise. Verificou-se também que a reação segue uma cinética de primeira ordem para concentrações iniciais de estireno, entre 15,27 e 57,25 ppm, a $30^{\circ} \mathrm{C}$. A análise cromatográfica das amostras coletadas durante os experimentos de fotodegradação identificou o benzaldeído como um dos intermediários dessa reação. Além disso, a adição de $\mathrm{H}_{2} \mathrm{O}_{2}$ aumentou a velocidade de degradação.
\end{abstract}

The aqueous styrene photocatalytic degradation reaction was evaluated using $\mathrm{TiO}_{2} \mathrm{P}-25$ (Degussa) as a catalyst. These experiments were accomplished in a batch slurry reactor with temperature control and a UV lamp. The effects of the initial styrene concentration, the catalyst concentration, the hydrogen peroxide addition and the initial $\mathrm{pH}$ of the solution on the reaction were evaluated. The experimental results showed that in $90 \mathrm{~min}, 95 \%$ of the initial styrene was degraded by photocatalysis. It was verified that the styrene degradation rate fits a pseudo-first-order kinetics for initial styrene concentrations between 15.27 and $57.25 \mathrm{ppm}$, at $30^{\circ} \mathrm{C}$. The chromatographic analysis of the samples collected during the photocatalytic degradation revealed benzaldehyde as one of the intermediates. The addition of $\mathrm{H}_{2} \mathrm{O}_{2}$ accelerated the degradation reaction until the system reached a certain optimum peroxide concentration in the reactor. Further $\mathrm{H}_{2} \mathrm{O}_{2}$ additions resulted in a reaction rate reduction.

Keywords: styrene, photocatalysis, $\mathrm{TiO}_{2}$, reaction kinetics, benzaldehyde

\section{Introduction}

Styrene is potentially present in food, drinking water, indoor air or the environment as a result of direct releases or leaching of residual monomer from polymers. This toxic compound has a detrimental effect on wildlife and marine organisms, and it is potentially carcinogenic. ${ }^{1}$

In spite of its toxicity, the literature dealing with styrene photocatalytic degradation is scarce. Few articles regarding gas-phase photocatalytic oxidation of styrene in a tubular reactor ${ }^{2}$ and in a fluidized-bed ${ }^{3,4}$ are available, but nothing regarding contaminated wastewater is available. Styrene solubility in water is $300 \mathrm{mg} \mathrm{L}^{-1}\left(20^{\circ} \mathrm{C}\right)$, and its vapor

*e-mail: marla@enq.ufrgs.br pressure is $5 \mathrm{~mm} \mathrm{Hg}$ at $20^{\circ} \mathrm{C}$ and $1 \mathrm{~atm} .{ }^{1,5}$ These solubility characteristics allow styrene to be a major pollutant in water. Estimated half-lives of styrene in surface waters range from $1 \mathrm{~h}$ in a shallow body of water to 13 days in a lake. The half-life of styrene in ground water is estimated at 4-30 weeks. ${ }^{5}$

Photocatalysis is one of the advanced oxidation processes and is based on the formation of the $\mathrm{HO}^{*}$ radical, a highly oxidizing agent. There are many studies in the literature dealing with wastewater photocatalytic treatment. Efforts are underway for dealing with dyes, ${ }^{6,7}$ as well as water polluted with fungicides, ${ }^{8,9}$ antibiotics ${ }^{10,11}$ and insecticides, ${ }^{12}$ among other toxic molecules. ${ }^{13}$

In this study, the photocatalytic degradation of styrene in water was investigated using $\mathrm{TiO}_{2}$ as a catalyst. The goals 
were (i) to evaluate the kinetics of styrene disappearance and (ii) to examine the effect of several parameters including catalyst mass, initial styrene concentration, oxidants addition and $\mathrm{pH}$ change.

\section{Experimental}

Reagents

Titanium dioxide P-25 (Degussa) was used as a catalyst. This product contains mainly anatase and has a specific surface area of $50 \mathrm{~m}^{2} \mathrm{~g}^{-1}$ and a particle size of $30 \mathrm{~nm}$. The reactant, styrene, was kindly provided by the Innova Petroquímica Company. The water used was previously distilled. $\mathrm{HCl}$ and $\mathrm{NaOH}$ solutions were used to adjust the $\mathrm{pH}$.

\section{Apparatus}

The photocatalytic bath reactor used in these experiments was made from cylindrical glass with a $13 \mathrm{~cm}$ height and a $10.5 \mathrm{~cm}$ inner diameter. The reactor was provided with a jacket for water circulation.

A $28 \mathrm{~W}$ UV lamp $\left(3.8 \mathrm{~mW} \mathrm{~cm}^{-2}\right)$ was the radiation source used, and it emitted light with wavelengths between 320 and $400 \mathrm{~nm}$, with a maximum of $365 \mathrm{~nm}$ (the optimum for $\left.\mathrm{TiO}_{2}\right) \cdot{ }^{14}$ The lamp position was fixed so that the distance between the lamp and the reactor top was $2 \mathrm{~cm}$, without variation from one experiment to another. In order to avoid styrene mass transfer to the vapor phase, the reactor was covered with a PVC film.

To evaluate the possible influence of the PVC film on the incident radiation at the reactor surface, the film used to cover the reactor was analyzed to determine its transmittance. At $365 \mathrm{~nm}$, the film reduces the transmittance by approximately $12.9 \%$.

\section{Photodegradation and adsorption tests}

Styrene solutions were prepared and maintained under agitation for $8 \mathrm{~h}$, after that $\mathrm{pH}$ was adjusted if necessary. The reactor was charged with $900 \mathrm{~mL}$ of styrene solution and $\mathrm{TiO}_{2}$, isolated with the PVC film and operated in the dark (without UV irradiation) during the first $40 \mathrm{~min}$ so that the equilibrium adsorption of organic molecules by the catalyst was reached. Each experiment was accomplished using agitation and constant temperature. Before each photodegradation experiment, the UV lamp was preheated for $30 \mathrm{~min}$ to obtain a constant light intensity during the tests. Sample collections were done using a syringe, and the samples were then centrifuged for catalyst removal. A
$2 \mathrm{~mL}$ aliquot was collected after $0,15,30,60$, and $90 \mathrm{~min}$ of reaction time.

To evaluate the amount of available oxygen for the reaction, the dissolved oxygen was measured during one typical experiment. This was done using the electrodes of a Biostat ${ }^{\circledR}$ Fermentator (B. Braun Biotech International). The $\mathrm{pH}$ was also measured during this experiment.

Analysis

The styrene concentration was monitored using a gas chromatograph (Auto System XL, Perkin-Elmer) equipped with a flame ionization detector (FID). The styrene was quantified using calibration curves.

The reaction intermediates were analyzed by a gas chromatograph (Agilent-6890) coupled to a mass selective detector (Agilent-5973). Total organic carbon (TOC) was analyzed by a StarTOC Benchtop TOC analyzer (Star Instruments Inc.). The influence of the PVC film on the incident radiation at the reactor surface was analyzed by a UV-Vis spectrophotometer (VARIAN Cary $300^{\circledR}$ ).

The radiant flux of the UV source was determined by a digital radiometer (EW-09811-50 Cole-Parmer Instruments Co., half bandwidth of $12 \mathrm{~nm} \pm 2$ and accuracy 5\%).

\section{Results and Discussion}

\section{Adsorption}

Several preliminary experiments were performed before initiating the styrene photocatalytic degradation tests. First, adsorption tests were carried out in the dark in order to determine the minimum styrene-catalyst contact time that guaranteed adsorption equilibrium at the catalyst surface for each of the $\mathrm{pH}$ values used. This test was important to ensure that when initiating the reaction by lamp activation, the disappearance of styrene was due to photocatalytic degradation. The results are shown in Figure 1.

The styrene was adsorbed onto the $\mathrm{TiO}_{2}$ surface, and the adsorption equilibrium was reached at $40 \mathrm{~min}$. The equilibrium concentration of the styrene solution was determined after adsorption, and the initial concentration of styrene for kinetic analysis was also determined. The $\mathrm{pH}$ effect is discussed later in this work.

\section{Styrene loss for the environment and degradation}

Even though the reactor was covered with a PVC film in all experiments, it was necessary to evaluate the styrene lost to the atmosphere under the test conditions. Five tests were carried out without $\mathrm{TiO}_{2}$ and with UV light. For these 


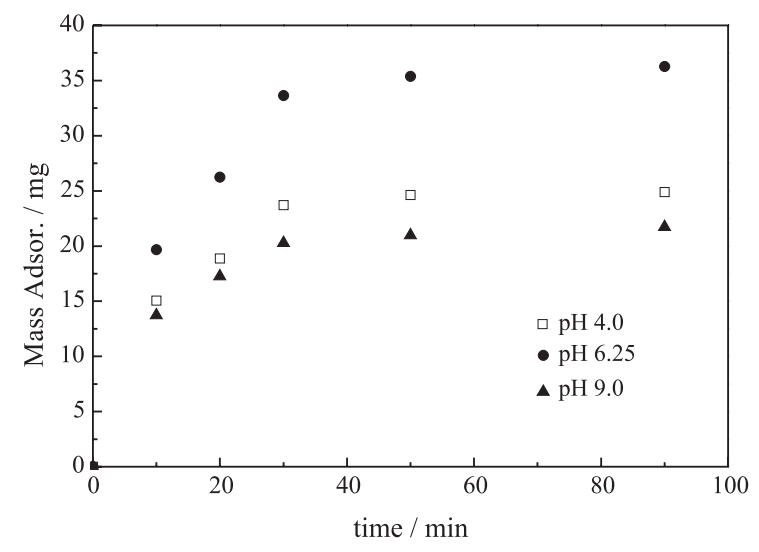

Figure 1. Styrene adsorption on the $\mathrm{TiO}_{2}$ surface $\left(\mathrm{T}=30{ }^{\circ} \mathrm{C}\right.$, $\mathrm{C}_{0}=55.3 \mathrm{mg} \mathrm{L}^{-1}$ and $\left.\mathrm{C}_{\text {cat }}=0.55 \mathrm{~g} \mathrm{~L}^{-1}\right)$.

tests, the reactor was maintained at the standard operation conditions $(\mathrm{T}, \mathrm{pH}, \mathrm{rpm})$. It was observed that the styrene loss to the environment is a reproducible phenomenon and has a minor role, as evident in Figure 2. This figure also shows that non-appreciable styrene photodegradation occurs after 90 min of irradiation without $\mathrm{TiO}_{2}$ (photolysis). The photolysis results presented in this Figure had been corrected: the amount of styrene lost to the atmosphere was added point to point, in order to allow that each process is visualized individually. On the other hand, when the styrene solution mixed with $\mathrm{TiO}_{2}$ was exposed to UV radiation, a fast decrease in the styrene concentration occurred, and $95 \%$ degradation for an initial concentration of $24.2 \mathrm{mg} \mathrm{L}^{-1}$ was reached in $90 \mathrm{~min}$. The styrene concentration reached the GC limit of detection (approximately $0.001 \mathrm{mg} \mathrm{L}^{-1}$ ) after $180 \mathrm{~min}$.

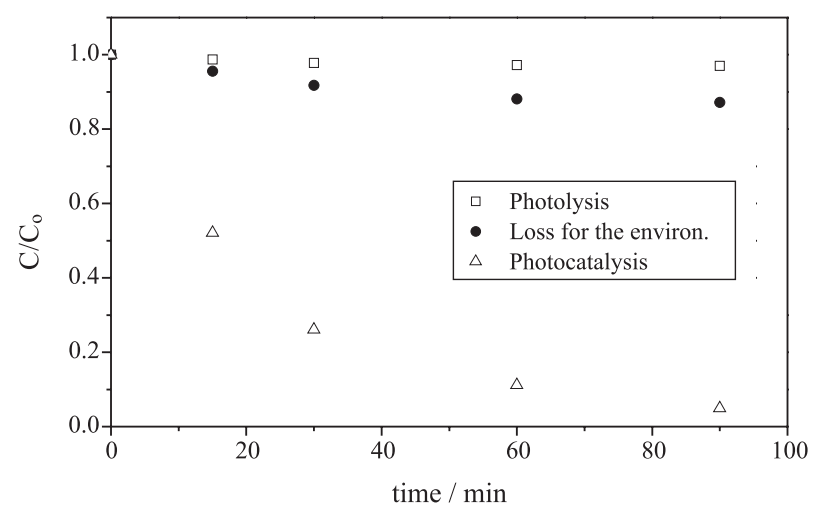

Figure 2. Styrene concentration variation with time $\left(\mathrm{T}=30^{\circ} \mathrm{C}, \mathrm{pH} 6.25\right.$, $\mathrm{C}_{0}=24.2 \mathrm{mg} \mathrm{L}^{-1}$ and $\left.\mathrm{C}_{\text {cat }}=0.55 \mathrm{~g} \mathrm{~L}^{-1}\right)$.

The representative rate of styrene photodegradation was obtained only during the first $30 \mathrm{~min}$ because, after this initial time, there could be interference from intermediate product(s) formed. This procedure allows for the determination of a pseudo-first-order apparent rate constant of $0.0445 \mathrm{~min}^{-1}$, which is shown in Figure 3. In this Figure, " $\mathrm{C}_{\mathrm{o}}$ " represents the initial concentration of styrene and "C" is its instantaneous concentration.

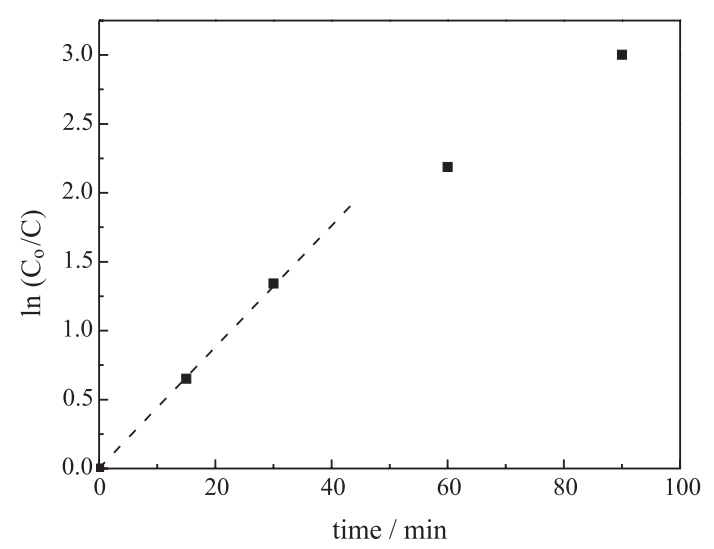

Figure 3. Relationship between $\ln \left(\mathrm{C}_{0} / \mathrm{C}\right)$ and irradiation time $\left(\mathrm{T}=30^{\circ} \mathrm{C}\right.$, $\mathrm{pH}$ 6.0, $\mathrm{C}_{0}=25 \mathrm{mg} \mathrm{L}^{-1}$ and $\left.\mathrm{C}_{\text {cat }}=0.55 \mathrm{~g} \mathrm{~L}^{-1}\right)$.

\section{Measures of dissolved oxygen and $\mathrm{pH}$ during the reaction}

The oxygen is important in the photocatalytic process, being usually continuously injected in the reactor. In the present study was necessary to cover the reactor with a PVC film and oxygen was not supplying to the reactor. So, to evaluate the oxygen readiness during the reaction, measures of the dissolved oxygen were done. The results are presented in Table 1. In this table the $\mathrm{pH}$ behavior is also presented.

As can be observed, in 90 min reaction the oxygen consumption was of approximately $18 \%$. The remaining oxygen is enough to guarantee the process efficiency. It is also possible to observe in the Table 1 that the solution $\mathrm{pH}$ varies from 6.2 to 5.5 . The $\mathrm{pH}$ reduction is due, mainly, to the formation of $\mathrm{CO}_{2}$ and $\mathrm{H}^{+}$. Besides, the benzaldehyde

Table 1. Dissolved oxygen and $\mathrm{pH}$

\begin{tabular}{lcc}
\hline time / min & $\mathrm{pH}$ & $\mathrm{O}_{2} /(\%)$ \\
\hline 0 & 6.27 & 100 (saturated) \\
20 & 6.19 & 95.46 \\
40 & 6.13 & 90.75 \\
60 & 6.02 & 86.34 \\
80 & 5.97 & 82.71 \\
90 & 5.91 & 81.44 \\
100 & 5.89 & 80.5 \\
120 & 5.79 & 78.79 \\
140 & 5.69 & 77.06 \\
160 & 5.58 & 76.31 \\
180 & 5.48 & 75.51 \\
\hline
\end{tabular}


formation also takes to the decrease of this variable. The $\mathrm{pH}$ plays an important role in the photocatalytic process and it will be further discussed.

\section{Effect of initial styrene concentration}

The effect of initial styrene concentration was evaluated over the range of 15.3 to $57.3 \mathrm{mg} \mathrm{L}^{-1}$, corresponding to $1.47 \times 10^{-4}$ and $5.50 \times 10^{-4} \mathrm{~mol} \mathrm{~L}^{-1}$. Figure 4 shows the normalized concentration against irradiation time for several initial concentrations of styrene.

Increasing styrene concentration decreases its degradation rate. Similar results have been presented for the photocatalytic oxidation of other organic compounds. ${ }^{15-17}$ According to Ishiki et al. ${ }^{18}$ this decrease may be due to the fixed active site number at the $\mathrm{TiO}_{2} / \mathrm{H}_{2} \mathrm{O}$ interface. Therefore, at low styrene concentrations, a larger number of water molecules will be adsorbed onto the available $\mathrm{TiO}_{2}$ particles, producing hydroxyl radicals and leading to a rapid oxidation process. On the other hand, at higher styrene concentrations, there is a smaller ratio of water molecules to free active sites, because the number of active sites remains the same. Consequently, competitive adsorption between the styrene and water molecules increases and leads to a decrease in the degradation rate.

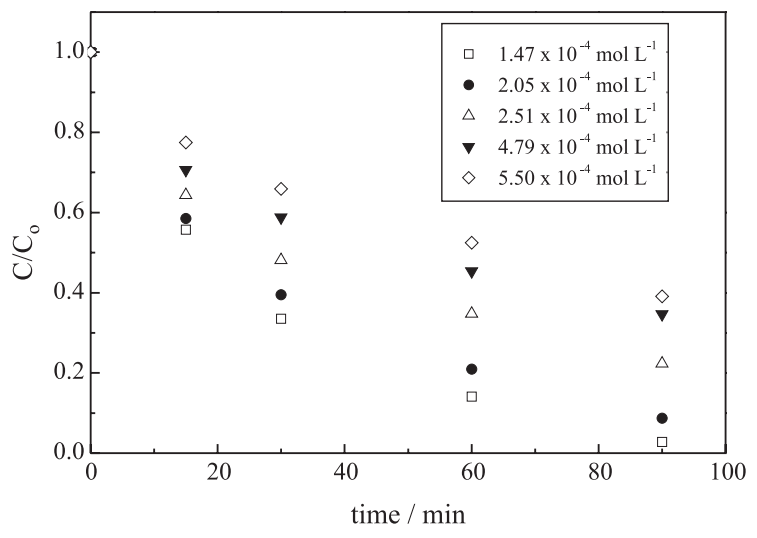

Figure 4. The effect of initial styrene concentration on the photodegradation rate $\left(\mathrm{T}=30^{\circ} \mathrm{C}, \mathrm{pH} 6.0\right.$ and $\left.\mathrm{C}_{\text {cat }}=0.55 \mathrm{~g} \mathrm{~L}^{-1}\right)$.

The Langmuir-Hinshelwood rate expression has been successfully used to describe the relationship between the heterogeneous photocatalyst degradation rate and the initial pollutant concentration. ${ }^{19-22}$ In this study, a reasonable agreement $\left(\mathrm{R}^{2}=0.9687\right)$ was obtained between the experimental results and the linear form of the L-H expression (equation 1). This expression used values of $1.46 \times 10^{-5} \mathrm{~mol} \mathrm{~L}^{-1} \mathrm{~min}^{-1}$ and $2.92 \times 10^{3} \mathrm{~mol}^{-1} \mathrm{~L}$ for the reaction kinetic constant $(\mathrm{k})$ and the adsorption constant $(\mathrm{K})$, respectively. This indicates that the photodegradation rate of styrene can be described by the LangmuirHinshelwood model.

$$
\frac{1}{\mathrm{r}_{0}}=\frac{1}{\mathrm{k}}+\frac{1}{\mathrm{kK}} \frac{1}{\mathrm{C}_{0}}
$$

Under our experimental conditions, the apparent pseudofirst-order constant $\left(0.0445 \mathrm{~min}^{-1}\right)$ is the multiplication product of the adsorption constant and the kinetic constant, because for dilute solutions the denominator of the L-H expression approaches unity. If the constants obtained through the linear adjustment are multiplied, the outcome is $0.0425 \mathrm{~min}^{-1}$. The small difference between the measured rate constant and the predicted value confirmed the quality of the experimental result.

\section{Effect of catalyst concentration}

The effect of the catalyst concentration in the mixture is shown in Figure 5, which presents the values of the pseudo-first-order apparent kinetic constant for several initial catalyst concentrations. The reaction kinetic constant increases as the catalyst concentration is incremented from 0.11 to $0.55 \mathrm{~g} \mathrm{~L}^{-1}$. Above $0.55 \mathrm{~g} \mathrm{~L}^{-1}$, the value decreases. It should be emphasized that these results are dependent on the experimental apparatus used in this work.

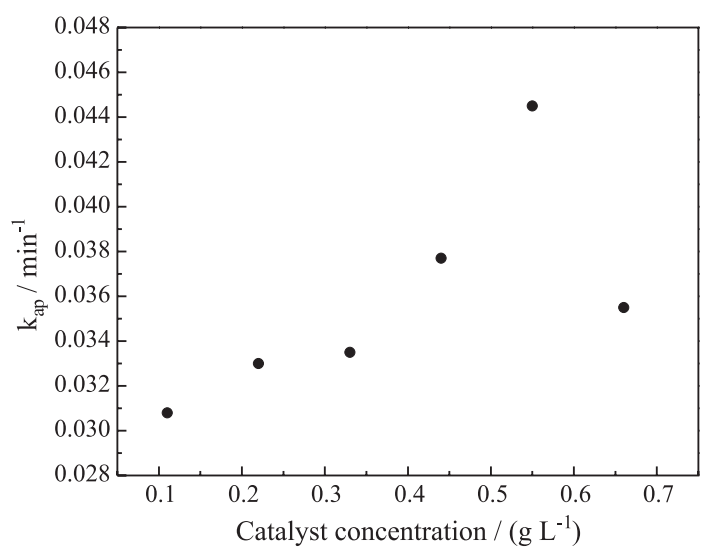

Figure 5. Variation of the apparent kinetics constant with the catalyst concentration $\left(\mathrm{T}=30^{\circ} \mathrm{C}, \mathrm{C}_{0}=25 \mathrm{mg} \mathrm{L}^{-1}\right.$ and $\mathrm{pH}$ 6.0).

Similar behavior was observed by several authors for different pollutants. ${ }^{15,23-25}$ With the increased amount of catalyst, the number of photons absorbed and the number of molecules adsorbed also increased, due to an increase in the number of $\mathrm{TiO}_{2}$ particles. The density of particles in the area of illumination also increased, and the degradation rate therefore increased. However, a further increase in catalyst concentration implies that some photocatalyst particles may not receive enough energy to start styrene 
oxidation. Gogate and Pandit ${ }^{26}$ attributed this behavior to the increase in opacity, which leads to a decrease in the passage of radiation through the reactor.

During catalysis, large amounts of particle aggregation may also occur, thus reducing the interfacial area between the substratum and catalyst. This decrease in area causes a decrease in the number of surface active sites and consequently decreases the photodegradation efficiency. ${ }^{20,27}$ It should be noted that the number of photons that reaches the reactor surface is constant and that their number is in great excess compared to that necessary for the reaction.

\section{Effect of initial $p H$}

The efficiency of photocatalytic degradation is affected by the $\mathrm{TiO}_{2}$ surface properties, the molecules charge and the hydroxyl radical concentration. These properties depend on the $\mathrm{pH}$.

The effect of $\mathrm{pH}$ on styrene photocatalytic degradation was evaluated in this study. Figure 6 shows the apparent pseudo-first order kinetic constant values for several initial $\mathrm{pH}$ conditions.

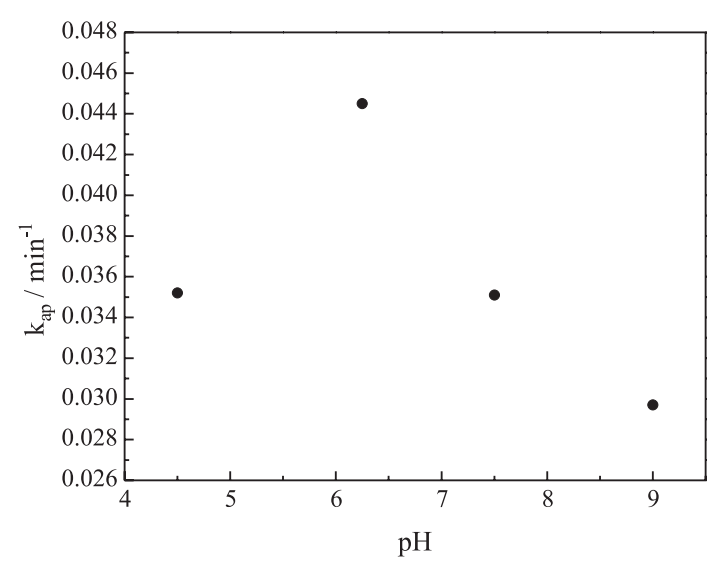

Figure 6. Effect of initial $\mathrm{pH}$ on the styrene degradation rate constant $\left(\mathrm{C}_{0}=25 \mathrm{mg} \mathrm{L}^{-1}, \mathrm{C}_{\text {cat }}=0.55 \mathrm{~g} \mathrm{~L}^{-1}, \mathrm{~T}=30^{\circ} \mathrm{C}\right)$.

Electrostatic attraction or repulsion between the catalyst's surface and the organic molecule depends on the ionic form of the organic compound (anionic or cationic) and the surface charge. ${ }^{21}$ The electric charge of a solid surface in an aqueous solution is determined by the zero point charge (ZPC). At $\mathrm{pH}$ values lower than ZPC, the catalyst's surface is positively charged, and at higher $\mathrm{pH}$ values it is negatively charged. The $\mathrm{ZPC}$ of the $\mathrm{TiO}_{2}$ catalyst (degussa P25) is $\mathrm{pH}$ 6.8..$^{28-30}$

Figure 6 shows that the reaction presented a maximum degradation rate at $\mathrm{pH} 6.0$ (the natural $\mathrm{pH}$ ). At $\mathrm{pH} 6.0$, the $\mathrm{TiO}_{2}$ surface was weakly charged (near ZPC), a situation in which molecules probably reach the catalyst surface more easily. This phenomenon facilitates the adsorption of the pollutant and consequently permits the degradation rate to reach its maximum value..$^{21,31}$

At acid $\mathrm{pH}$ (4.0), the adsorption was relatively low. This effect is due to $(i) \mathrm{TiO}_{2}$ particle agglomeration that reduces styrene adsorption and photon absorption at low $\mathrm{pH}$ values, and (ii) the $\mathrm{TiO}_{2}$ surface is positively charged $\left(\mathrm{TiOH}_{2}{ }^{+}\right)$at low $\mathrm{pH}$. When the $\mathrm{pH}$ is adjusted with $\mathrm{HCl}$, as in this study, the $\mathrm{Cl}^{-}$anions are also adsorbed, and there is competition between anion adsorption and styrene molecule adsorption. However, it was necessary to add only $0.18 \mathrm{~mL}$ of $\mathrm{HCl}\left(0.1 \mathrm{~mol} \mathrm{~L}^{-1}\right)$ to reach the $\mathrm{pH} 4$. This corresponds at $0.8 \mathrm{mg} \mathrm{L}^{-1}$ of chloride, insignificant amount when compared with the styrene amount present in the solution $\left(25 \mathrm{mg} \mathrm{L}^{-1}\right)$. Thus the reduction of catalyst activity at $\mathrm{pH} 4$ is not due to competition. Agglomeration and sedimentation of the $\mathrm{TiO}_{2}$ particles were observed ${ }^{29}$ when $2000 \mathrm{mg} \mathrm{L}^{-1}$ of $\mathrm{TiO}_{2}$ was used. In this work, the maximum catalyst concentration used was $650 \mathrm{mg} \mathrm{L}^{-1}$.

On the other hand, at basic $\mathrm{pH}$, the $\mathrm{TiO}_{2}$ surface is negatively charged $\left(\mathrm{TiO}^{-}\right)$, and the $\mathrm{Na}^{+}$ions adsorption competes with organic molecule adsorption. Moreover, in the alkaline solution there is repulsion between the negatively charged surface of photocatalyst and the hydroxide anions. This repulsion could prevent the formation of $\mathrm{HO}^{\circ}$ and thus decrease the rate of photooxidation..$^{29}$

\section{Effect of $\mathrm{H}_{2} \mathrm{O}_{2}$ addition}

The major energy-wasting step in the photocatalytic reaction is electron-hole recombination. The prevention of this recombination is achieved by adding a proper electron donor or an acceptor to the system. Usually, molecular oxygen and hydrogen peroxide are used as electrons acceptors in heterogeneous photocatalyzed reactions.

In order to investigate the effect of $\mathrm{H}_{2} \mathrm{O}_{2}$ addition on styrene photodegradation, experiments utilizing several $\mathrm{H}_{2} \mathrm{O}_{2}$ concentrations $\left(1.93 ; 3.86 ; 5.79 ; 7.72 ; 9.65 \mathrm{mmol} \mathrm{L}^{-1}\right)$ were conducted. The results are presented in Figure 7 . The degradation rate had a maximum at the optimum peroxide concentration of $5.8 \mathrm{mmol} \mathrm{L}^{-1}$.

The addition of hydrogen peroxide increases the formation of hydroxyl radical via a mechanism proposed by Ollis, ${ }^{32}$ where $\mathrm{H}_{2} \mathrm{O}_{2}$ is considered a better electron acceptor than oxygen, as shown in equation 2 .

$\mathrm{TiO}_{2}\left(\mathrm{e}^{-}\right)+\mathrm{H}_{2} \mathrm{O}_{2} \rightarrow \mathrm{TiO}_{2}+\mathrm{OH}^{-}+\mathrm{HO}^{\bullet}$

Therefore, the photocatalytic degradation rate is expected to increase with the elevated amount of $\mathrm{H}_{2} \mathrm{O}_{2}$ in the system. However, $\mathrm{H}_{2} \mathrm{O}_{2}$ greatly decreased the degradation 


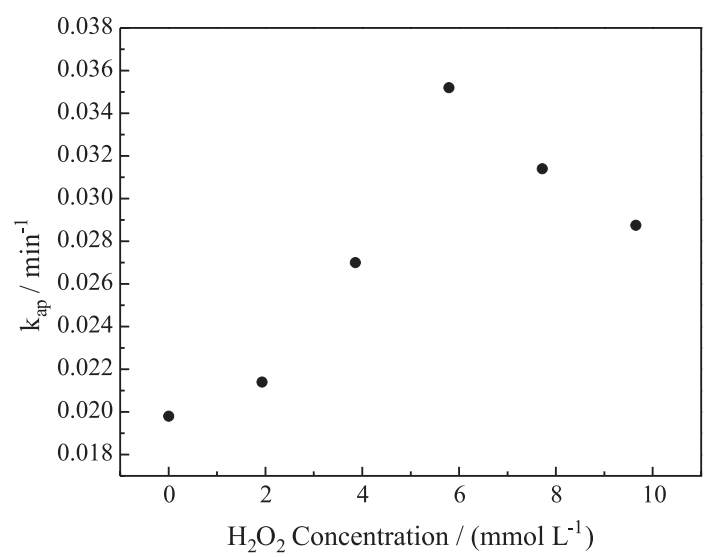

Figure 7. Effect of $\mathrm{H}_{2} \mathrm{O}_{2}$ on the styrene degradation rate $\left(\mathrm{C}_{\text {cat }}=0.55 \mathrm{~g} \mathrm{~L}^{-1}\right.$, $\mathrm{C}_{0}=25 \mathrm{mg} \mathrm{L}^{-1}, \mathrm{~T}=30^{\circ} \mathrm{C}$ and $\mathrm{pH} 6.0$ ).

rate. This negative effect of a high $\mathrm{H}_{2} \mathrm{O}_{2}$ concentration may be due to the formation of $\mathrm{HO}_{2}^{*}$, a species that is significantly less reactive than $\mathrm{HO}^{*} .^{33}$ The excess $\mathrm{H}_{2} \mathrm{O}_{2}$ molecules on the catalyst surface may also act as powerful scavengers of radicals, ${ }^{21,34}$ as shown in equations 3 and 4 . Competition for adsorption by the styrene and hydrogen peroxide still occurs. ${ }^{35,36}$

$\mathrm{H}_{2} \mathrm{O}_{2}+\mathrm{HO}^{*} \rightarrow \mathrm{H}_{2} \mathrm{O}+\mathrm{HO}_{2}^{*}$

$\mathrm{HO}_{2}^{*}+\mathrm{HO}^{*} \rightarrow \mathrm{H}_{2} \mathrm{O}+\mathrm{O}_{2}$

\section{Detection of intermediates, carbon and oxygen balance}

The chromatographic analysis of the samples collected during the photocatalytic degradation of styrene revealed benzaldehyde as one of the intermediates.

Styrene clearly offers two main possibilities for hydroxyl radical attack: the ring or the double bond in the side chain. The reactions involve eletrophilic substitution in the aromatic ring or free-radical substitution in the side chain. ${ }^{37}$ Benzaldehyde formation at relatively great amounts is evidence for the preferential attack by radical ${ }^{\circ} \mathrm{OH}$ on the styrene side chain.

Experiments were carried out in order to simultaneously analyze the styrene concentration, the benzaldehyde concentration and the total organic carbon (TOC). The results, which are presented in Figure 8, were used to perform a mass balance. Using this mass balance, the $\mathrm{CO}_{2}$ formed during the reaction was calculated, and the results are summarized in Table 2.

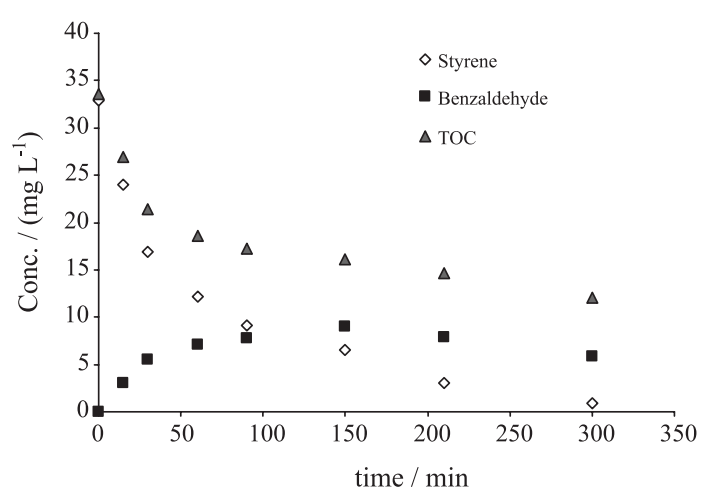

Figure 8. Total organic carbon and benzaldehyde formation during the photocatalytic degradation of styrene $\left(\mathrm{C}_{0}=32.9 \mathrm{mg} \mathrm{L}^{-1}, \mathrm{~T}=30^{\circ} \mathrm{C}, \mathrm{pH} 6.25\right.$, $\mathrm{C}_{\text {cat }}=0.55 \mathrm{~g} \mathrm{~L}^{-1}$ and radiant flux $=3.8 \mathrm{~mW} \mathrm{~cm}^{-2}$ ).

Column $\mathrm{V}$ in Table 2 presents the carbon balance $\left\{\mathrm{TOC}_{(\mathrm{t})}-\left[\mathrm{C}_{(\mathrm{t}) \text { in styrene }}+\mathrm{C}_{(\mathrm{t}) \text { in benzaldehyde }}\right]\right\}$. Its non-null results reveal the formation of unidentified molecules, which are present in significant amount after 90 min of reaction time. One may infer that these molecules are products of benzaldehyde photodegradation, because they only appeared when a significant amount of benzaldehyde was present. The identification of intermediates is beyond the scope of this work. Column VII presents the values for $\left[\mathrm{TOC}_{(\mathrm{t}=0)}-\mathrm{TOC}_{(\mathrm{t})}\right]$, which indicates the amount of $\mathrm{CO}_{2}$ formed.

Table 2. Carbon mass balance results

\begin{tabular}{|c|c|c|c|c|c|c|}
\hline I & II & III & IV & V & VI & VII \\
\hline time / min & $\begin{array}{c}\text { Carbon } \\
\text { in styrene / } \\
\left(\mathrm{mol} \mathrm{L}^{-1}\right)\end{array}$ & $\begin{array}{c}\text { Carbon in } \\
\text { benzaldehyde / } \\
\left(\mathrm{mol} \mathrm{L}^{-1}\right)\end{array}$ & $\begin{array}{c}\text { TOC / } \\
\left(\mathrm{mol} \mathrm{L}^{-1}\right)\end{array}$ & $\begin{array}{l}\text { Carbon in molecules } \\
\text { not identified / } \\
\left(\mathrm{mol} \mathrm{L}^{-1}\right)\end{array}$ & $\begin{array}{c}\text { Carbon in molecules } \\
\text { not identified / } \\
(\%)\end{array}$ & $\begin{array}{c}\mathrm{CO}_{2} \\
\text { concentration / } \\
\left(\mathrm{mol} \mathrm{L}^{-1}\right)\end{array}$ \\
\hline 0 & $2.53 \times 10^{-3}$ & 0 & $2.53 \times 10^{-3}$ & ca. 0 & ca. 0 & 0 \\
\hline 15 & $1.84 \times 10^{-3}$ & $2.03 \times 10^{-4}$ & $2.03 \times 10^{-3}$ & ca. 0 & ca. 0 & $5.02 \times 10^{-4}$ \\
\hline 30 & $1.30 \times 10^{-3}$ & $3.64 \times 10^{-4}$ & $1.61 \times 10^{-3}$ & ca. 0 & ca. 0 & $9.21 \times 10^{-4}$ \\
\hline 60 & $9.38 \times 10^{-4}$ & $4.71 \times 10^{-4}$ & $1.40 \times 10^{-3}$ & ca. 0 & ca. 0 & $1.13 \times 10^{-3}$ \\
\hline 90 & $6.99 \times 10^{-4}$ & $5.14 \times 10^{-4}$ & $1.29 \times 10^{-3}$ & $8.20 \times 10^{-5}$ & 6.3 & $1.23 \times 10^{-3}$ \\
\hline 150 & $5.03 \times 10^{-4}$ & $5.95 \times 10^{-4}$ & $1.21 \times 10^{-3}$ & $1.11 \times 10^{-4}$ & 9.2 & $1.32 \times 10^{-3}$ \\
\hline 210 & $2.32 \times 10^{-4}$ & $5.24 \times 10^{-4}$ & $1.10 \times 10^{-3}$ & $3.42 \times 10^{-4}$ & 31.2 & $1.43 \times 10^{-3}$ \\
\hline 300 & $7.21 \times 10^{-5}$ & $3.86 \times 10^{-4}$ & $9.08 \times 10^{-4}$ & $4.50 \times 10^{-4}$ & 49.5 & $1.62 \times 10^{-3}$ \\
\hline
\end{tabular}




\section{Conclusions}

The photocatalytic degradation of styrene in an aqueous solution was studied in a bath slurry reactor irradiated with a UV light source and using a titanium dioxide as a catalyst.

Under these study conditions, styrene degradation is a photocatalytic process because styrene concentration reduction was not observed in the absence of either the catalyst or radiation. The adsorption equilibrium was reached within $40 \mathrm{~min}$ for three tested $\mathrm{pH}$ values (4.0, 6.25, and 9.0). In addition, the amount of adsorbed styrene depended on the solution $\mathrm{pH}$. In this case, the adsorption maximum occurred at $\mathrm{pH} 6.25$.

The styrene degradation kinetics can be approximated by a pseudo-first order model with a reaction rate dependent on the initial concentration of styrene, the $\mathrm{TiO}_{2}$ concentration, the $\mathrm{pH}$ and the $\mathrm{H}_{2} \mathrm{O}_{2}$ concentration. The degradation rate decreased with increasing initial concentrations of styrene, and it increased with increasing catalyst concentrations up to a maximum of $0.55 \mathrm{~g} \mathrm{~L}^{-1}$. Additionally, the degradation rate was maximal when the $\mathrm{pH}$ was approximately 6.25 and the $\mathrm{H}_{2} \mathrm{O}_{2}$ concentration was $5.8 \mathrm{mmol} \mathrm{L}^{-1}$.

According to the Langmuir-Hinshelwood kinetic model, the kinetic constant $(\mathrm{k})$ and adsorption constant $(\mathrm{K})$ are $1.46 \times 10^{-5} \mathrm{~mol} \mathrm{~L}^{-1} \mathrm{~min}^{-1}$ and $2.92 \times 10^{3} \mathrm{~L} \mathrm{~mol}^{-1}$, respectively.

The CG-MS results revealed benzaldehyde formation during styrene photocatalytic degradation, and the carbon balance indicated that at least one or more unknown organic molecule is formed and can be detected after $90 \mathrm{~min}$ of reaction time.

\section{Acknowledgments}

The authors are grateful to Degussa for supplying the $\mathrm{TiO}_{2}$ catalyst, Petrochemical Innova for supplying styrene and CAPES for financial support.

\section{References}

1. Gibbs, B. F.; Mulligan, C. N.; Ecotoxicol. Environ. Saf. 1997, 38,181 .

2. Kricheyskaya, M.; Preis, S.; J. Adv. Oxid. Technol. 2003, 6, 150.

3. Johnson, J. T.; Dziedzic, D.; Gross, K. B.; US Patent US7547418, 2009.

4. Lim, M; Zhou, Y; Wood, B; Guo, Y. N.; Wang, L. Z.; Rudolph, V; J. Phys. Chem. C 2008, 112, 19655.

5. National Toxicology Program U.S. Department of Health and Human Services; NTP-CERHR Expert Panel Report on the Reproductive and Developmental Toxicity of Styrene; June 2005; http://cerhr.niehs.nih.gov.
6. Soares, E. D.; Lansarin, M. A.; Moro, C. C.; Braz. J. Chem. Eng. 2007, 24, 29.

7. Garcia, J. C.; Simionato, J. I.; Almeida, V. C.; Palácio, S. M.; Rossi, F. L.; Schneider, M. V.; Souza, N. E.; J. Braz. Chem. Soc. 2009, 20, 1589.

8. Prestes, T. H.; Gibbon, D. O.; Moro, C. C.; Lansarin, M. A.; Quim. Nova 2010, 33, 798.

9. Lhome, L.; Brosillon, S; Wolbert, D.; J. Photochem. Photobiol., A 2007, 188, 34.

10. Elmolla, E. S.; Chaudhuri, M.; Desalination 2010, 252, 46.

11. Mouamfon, M. V. N.; Li, W. Z.; Lu, S. G.; Qiu, Z. F.; Chen, N.; Lin, K. F.; Environ. Technol. 2010, 31, 489.

12. Guzsvány, V. J.; Csanádi, J. J.; Lazic, S. D.; Gaál, F. F.; J. Braz. Chem. Soc. 2009, 20, 152.

13. Jo, W. K.; Yang, S. H.; Shin, S. H.; Yang, S. B.; Environ. Eng. Sci. 2011, 28, 43.

14. Zhao, J.; Wu, T.; Wu, K.; Oikawa, K.; Hidaka, H.; Serpone, N.; Environ. Sci. Technol.1998, 32, 2394.

15. Dijkstra, M. F. J.; Buwalda, H.; Jong, A. W. F.; Michorius, A.; Winkelman, J. G. M.; Beenackers, A. A. C. M.; Chem. Eng. Sci. 2001, 56, 547.

16. Peiró, A. M.; Ayllón, J. A.; Peral, J.; Doménech, X.; Appl. Catal., B 2001, 30, 359.

17. Gautam, S.; Kamble, S. P.; Sawant, S. B.; Pangarkar, V. G.; Chem. Eng. J. 2005, 110, 129.

18. Ishiki, R. R.; Ishiki, H. M.; Takashima, K.; Chemosphere 2005, $58,1461$.

19. Vidal, A.; Herrero, J.; Romero, M.; Sanchez, B.; Sanchez, M.; J. Photochem. Photobiol., A 1994, 79, 213.

20. Chen, D.; Ray, A. K.; Water Res.1998, 32, 3223.

21. Evgenidou, E.; Fytianos, K.; Poulios, I.; J. Photochem. Photobiol., A 2005, 175, 29.

22. Herrmann, J. M.; Top. Catal. 2005, 34, 49.

23. Barakat, M. A.; Tseng, J. M.; Huang, C. P.; Appl. Catal., B 2005, 59, 99.

24. Gogate, P. R.; Mujumdar, S.; Pandit, A. B.; Ind. Eng. Chem. Res. 2002, 41, 3370.

25. Andreozzi, R.; Caprio, V.; Insola, A.; J. Chem. Technol. Biotechnol. 2000, 75, 131.

26. Gogate, P. R.; Pandit, A. B.; Adv. Environ. Res. 2004, 8, 501.

27. Muruganandham, M.; Swaminathan, M.; Dyes Pigments 2006, $68,133$.

28. Zhang, F.; Zhao, J.; Shen, T.; Hidaka, H.; Pelizzetti, E.; Serpone, $\mathrm{N}$; Appl. Catal., B 1998, 15, 147.

29. Konstantinou, I. K.; Albanis, T. A.; Appl. Catal., B 2004, 49, 1.

30. Guillard, C.; Lachheb, H.; Houas, A.; Ksibi, M.; Elaloui, E.; Herrmann, J. M.; J. Photochem. Photobiol., A 2003, 158, 27.

31. Subramanian, V.; Pangarkar, V. G.; Beenackers, A. A. C. M.; Clean Prod. Process. 2000, $2,149$.

32. Ollis, D. F.; Serpone, N.; Pelizzetti, E.; Environ. Sci. Technol. 1991, 25, 1522. 
33. Senthilkumaar, S.; Porkodi, K.; J. Colloid Interface Sci. 2005, $288,184$.

34. Galindo, C.; Jacques, P.; Kalt, A.; Chemosphere 2001, 45, 997.

35. Hachem, C.; Bocquillon, F.; Zahraa, O.; Bouchy, M.; Dyes Pigm. 2001, 49, 117.
36. Malato, S.; Blanco, J.; Richter, C.; Braun, B.; Maldonado, M. I.; Appl. Catal., B 1998, 17, 347.

37. Morrison, R. T.; Boyd, R. N.; Organic Chemistry, $4^{\text {th }}$ ed.; Allyn and Bacon: Boston, MA, 1983.

Submitted: February 18, 2011

Published online: July 19, 2011 